\title{
Evaluation of Adhesive Materials Used in Wind Turbine Blades
}

\author{
Daniel O. Aikhuele ${ }^{10}$
}

Department of mechanical and Biomedical Engineering, Bells University of Technology, Ota, Nigeria.

Geliş / Received: 3.09.2018, Kabul / Accepted: 16.12.2019

\begin{abstract}
Adhesives bonds which are used extensively in the joining of FRP elements in wind turbine are considered a strong potential to replace the bolted joints found in most commercial aircraft. In this paper, a new method which is based on the integration of a Fuzzy Normalized-Hamming distance and Ideal Alternative (FL 2 DIA) model is proposed for the holistic evaluation of the different families of adhesive materials, which can be used for the formation of joints in mechanical systems and for joining wind turbine blades. The adhesive materials which are evaluated with respect to the fracture mechanics-based criteria use expert-based opinion to select the best alternative. The result from the study shows that Acrylic adhesive material $\left(\mathrm{A}_{3}\right)$ has the highest potential to be used for joining wind turbine blade and for the formation of joints in commercial aircraft. The study conclude that the procedure described for the evaluation of the adhesive material has led to the selection of the best structural adhesive to bond the FRP wind turbine blade. Also, it has revealed the suitability, rationality, and feasibility of using the proposed method for ranking the different alternatives as the result from the study have been fully compared with similar existing method (traditional fuzzy TOPSIS model) under the same condition. The comparison result which focuses on the ranking of the adhesive material shows total agreement with the proposed method.
\end{abstract}

Keywords: Adhesives bonds; wind turbine blade; Fuzzy Normalized-Hamming distance and Ideal Alternative (FL 2 DIA) model; Fibre Reinforced Plastic (FRP)

\section{Rüzgar Türbini Kanatlarında Kullanılan Yapıştırıcı Malzemelerin Değerlendirilmesi}

\section{$\ddot{O} \mathbf{z}$}

Rüzgar türbinindeki FRP elemanlarının birleştirilmesinde yaygın olarak kullanılan yapıştırıcı bağların, çoğu ticari uçakta bulunan civatalı bağlantıların yerine geçmek için güçlü bir potansiyeli olduğu düşünülmektedir. Bu makalede, mekanik sistemlerde mafsal (bağlantı) oluşumu ve rüzgar türbini kanatlarının birleştirilmesi için kullanılabilecek yapıştırıcı malzemelerin farklı ailelerinin bütünsel değerlendirmesi için Bulanık Normalize edilmiş-Hamming (sinyal) aralığ 1 ve İdeal Alternatif (FL $\left.{ }_{2} \mathrm{DIA}\right)$ modelinin entegrasyonuna dayanan yeni bir yöntem önerilmiştir. Kırılma mekaniği temelli kriterlere göre değerlendirilen yapıştırıcı malzemelerde, en iyi alternatifi seçmek için uzman temelli görüş kullanır. Çalışmanın sonucu, Akrilik yapıştırıcı malzemenin $\left(\mathrm{A}_{3}\right)$, rüzgar türbini kanadının birleştirilmesi ve ticari uçaklarda mafsal oluşumu için en yüksek potansiyele sahip olduğunu göstermektedir. Çalışma sonucu, yapıştırıcı malzemenin değerlendirilmesi için tanımlanan prosedür, FRP rüzgar türbini kanadının yapıştırılması için en iyi yapısal yapıştırıcının seçimine yol açmıştır. Ayrıca, aynı şart altında benzer mevcut yöntem (geleneksel bulanık TOPSIS modeli) ile tamamen karşılaştırılan çalışma, farklı alternatifleri sıralamak için önerilen yöntemi kullanmanın uygunluğu, rasyonalitesi ve fizibilitesini ortaya çıkarmıştır. Yapıştırıcı malzemenin sıralamasına odaklanan karşılaştırma sonucu, önerilen yöntemle tam uyumu göstermiştir.

Anahtar Kelimeler: Yapıştırıcı bağlar; Rüzgar türbini kanadı; Bulanık Normalize edilmiş-Hamming aralığı ve İdeal Alternatif (FL 2 DIA) modeli; Elyaf Takviyeli Plastik (FRP) 


\section{Introduction}

The attractive physical and mechanical properties of Fibre Reinforced Plastic (FRP) particularly its high strength and stiffness to weight characteristic has made it one of the most sorts after material for engineering designs. And has led to it increasing "Green" application (Mohammed, et al., 2015). Encouraged by these outstanding properties, the next generation of the Boeing 787 Dreamliner will have $50 \%$ of its structural element made of FRP. This is basically to help reduce the weight of the aircraft and minimize its fuel consumption and corresponding engine emissions (Milberg, 2015; Nicolais, et al., 2011). Also, the blades used in all most all the modern megawatt wind turbines systems designs are made from the FRP which have drastically reduced the inertia of the turbine system, thus improving its ability to harvest more energy from dynamic winds (Mishnaevsky et al., 2017; Schubel \& Crossley, 2012).

To fully take advantage and control of this material for the design and used for so many other engineering purposes, a suitable joining method is required. There are basically three existing methods for joining FRP materials, that is a bolting method, self-piercing rivet method and the use of adhesive bonding method (Oltean, et al., 2009). Several research study of bolt joining method for FRP materials have been conducted, the studies however all concluded that the bolting method is not suitable for joining FRP materials, most especially when used in complex designs like aircraft or wind turbine systems (Hollaway, 2011; Kelly, 2004; Khani, 2015). The following reasons however, have been put forward for such conclusion;
(1) The bolt joining method is capable of introducing structural discontinuity (stress raiser) which can result in fiber breakage and holes in the FRP material;

(2) The introduction of unwanted weight increase that diminishes the key reason for using FRP material in the first place; and

(3) The protruded bolt heads and nuts increase the aerodynamic drag of the assembly.

For the self-piercing rivet method and the adhesive bonding techniques, the research studies that have been conducted and the practitioners opinions gathered on the joining of FRP materials, all concluded that, none of the above-listed problems are recorded when they are joined. Also, the following economic advantages of the methods are listed as;

(1) Ease to design for flexibility and assembly in applications and

(2) Good aerodynamic characteristics which are critical for systems like megawatt wind turbine (Kroll et al., 2011).

Adhesives bonds which are used extensively in the joining of FRP elements in wind turbine system, are considered a strong potential to replace the bolted joints found in most of the commercial aircraft (Halliwell, 2012). With adhesive bonds in commercial aircraft, about $50 \%$ of the joint weight in the structure is bound to reduce. The adhesive bonds are formed by means of surface attachments; the reliability of these attachments is of critical importance to the design and manufacturing of their joints. Despite the many advantages of the application of adhesive bonding, it is still difficult to design, analyze and optimize adhesive bonded joints in mechanical systems (LeBacq, et al., 2002). Hence, the call for 
more research on the selection of suitable adhesive bond/family, from the long list of adhesives available for the formation of joints in mechanical system. As well as, research on the design, analysis and evaluation of structural adhesive joints types for enhancing the performance and understanding of structural behavior (Arenas, et al., 2012) in complex mechanical systems.

In addressing these issues, Samborsky, et al., (2009), applied the finite element analysis technique, where they explores the interactions between the thick adhesive joint geometry of turbine blade joints, as well as their local stress concentrations and pore hole locations. Campilho, et al., (2011), applied a finite element method to simulate the strength of adhesive joint, such that the strength of the bonded structure was predicted using strength of materials and fracture mechanics-based criteria. Tan \& Saha, (2007), investigates the deformation characteristics of GFRP-bonded RC beams under cyclic loading, the beam stiffness was found to reduce more significantly for larger load ranges and lower minimum load levels. The integration and understanding of these characteristics in these research studies, all work together with the major contributions on the design rules of structural adhesive bonded joints (Van, et al., 1998). Papini, et al., (1994), investigate the influence of varying geometric parameters like the adherend lengths and thicknesses on the strength of adhesively bonded joints using a single lap shear, cracked lap shear, and double strap joints.
Suárez, et al., (2003), discuss the selection and analysis of adhesively bonded joints, while Arenas et al., (2012), propose the analytical hierarchy process (AHP) method for selecting the best adhesive material from a list of five materials. The method used in this study however, is only suitable when the number of alternatives is discrete and based on the formation of a hierarchical problem structure that supports the interactions of conflicting criteria. In this present work, an alternative method is proposed. The new method which is based on the integration of a Fuzzy Normalized-Hamming distance and Ideal Alternative (FL2DIA) model is used for the holistic evaluation of the different families of adhesive materials used in the formation of joints in mechanical systems. The adhesive materials are evaluated with respect to some selected fracture mechanics-based criteria using expert-based opinion (see Table 1). The advantage of using this method is that, it is able to holistically account for all the different adhesive materials including those that were not mention in the previous studies as well as to access them with respect to the fracture mechanics-based criteria. Also, it requires less mathematic skills, repetitive adjustment of data and inconsistency in the final result.

The rest of the paper is organized as follows; in section 2, the method for the evaluation of the adhesive materials with respect to the fracture mechanics-based criteria is presented. The application of the method is presented in Section 3, while so closing remarks are presented in Section 4. 
Table 1: List of adhesive materials and the selected fracture mechanics-based criteria

\begin{tabular}{|c|c|c|c|}
\hline Adhesive Materials & Code & Adhesive Materials & Code \\
\hline Rubber adhesive & $\mathrm{A}_{1}$ & $\begin{array}{c}\text { PVA adhesive and related } \\
\text { emulsion systems }\end{array}$ & $\mathrm{A}_{11}$ \\
\hline Polyurethane & $\mathrm{A}_{2}$ & $\begin{array}{l}\text { Plastisols and elastosols } \\
\text { adhesive }\end{array}$ & $\mathrm{A}_{12}$ \\
\hline Acrylic & $\mathrm{A}_{3}$ & Cyanoacrylate & $\mathrm{A}_{13}$ \\
\hline Anaerobic & $\mathrm{A}_{4}$ & Silicone & $\mathrm{A}_{14}$ \\
\hline Solvent-based adhesive & $\mathrm{A}_{5}$ & & \\
\hline Hot-melt adhesive & $\mathrm{A}_{6}$ & $\begin{array}{c}\text { Fracture mechanics- } \\
\text { based criteria }\end{array}$ & Code \\
\hline Amino or urea-based adhesive & $\mathrm{A}_{7}$ & Fracture toughness & $\mathrm{C}_{1}$ \\
\hline Phenolics and resorcinolic adhesive & $\mathrm{A}_{8}$ & Crack-resistance & $\mathrm{C} 2$ \\
\hline Epoxy & $\mathrm{A}_{9}$ & Yield strength & C3 \\
\hline Polyimides and bismaleimides adhesive & $\mathrm{A}_{10}$ & Fatigue threshold & $\mathrm{C} 4$ \\
\hline
\end{tabular}

\section{Methodology}

\subsection{Fuzzy Normalized-Hamming distance and Ideal Alternative (FL2 DIA) model}

The Fuzzy Normalized-Hamming distance $\left(\mathrm{FL}_{2}\right)$, which is one of the distances methods applied for multi-criteria decision-making problems, is used to estimate the ideal distance between alternatives. Ideal alternatives are said to be virtual alternatives in which their criteria values are expressed as close as possible to ideal values. In this paper, the $\mathrm{FL}_{2}$ distance is integrated with the Ideal Alternative method originally proposed by Tran \& Boukhatem (2008). The $\mathrm{FL}_{2} \mathrm{DIA}$ method assumes that the determination of an ideal alternative is based on the optimum value of the criterion in which that alternative should achieve.

The FL ${ }_{2}$ DIA method belongs to the category of Multiple Attribute DecisionMaking (MADM) method originally developed by Lahby et al. (2012), and its implementation is similar to the M-TOPSIS model developed by Ren et al., (2007) and model developed by Ren et al., (2007) and its extensions presented in (Aikhuele \& Turan, 2017); Aikhuele \& Turan, 2016). Only that it uses the Mahalanobis distance method. The application of the $\mathrm{FL}_{2} \mathrm{DIA}$ method is based on its ability to evaluate the distance between ideal alternatives. It takes into consideration the correlation with different alternatives and it can be used in choosing or selecting optimal data for other applications. The steps for the implementation of the $\mathrm{FL}_{2} \mathrm{DIA}$ method are presented below;

Step 1. Engage a group of Experts/Decision Makers (DMs). With their expert opinion, construct a fuzzy decision matrix $D_{\text {nxm }}\left(x_{i j}\right)$ of the alternatives $\left(A_{i}\right)$ with respect to the fracture-based criteria $\left(C_{i}\right)$ presented in the introduction section, using linguistic variables and the fuzzy number (see Table 2) $x_{i j}=\left(a_{i j}, b_{i j}, c_{i j}\right), i=1,2, \ldots, m ; j=1, \ldots, n$ 


$$
D_{n x m}\left(x_{i j}\right)=\left[\begin{array}{cccc}
\left(a_{11}, b_{11}, c_{11}\right) & \left(a_{12}, b_{12}, c_{12}\right) & \ldots & \left(a_{1 n}, b_{1 n}, c_{1 n}\right) \\
\left(a_{21}, b_{21}, c_{21}\right) & \left(a_{22}, b_{22}, c_{22}\right) & \cdots & \left(a_{2 n}, b_{2 n}, c_{2 n}\right) \\
\vdots & \vdots & \ddots & \vdots \\
\vdots & \vdots & \ddots & \vdots \\
\left(a_{m 1}, b_{m 1}, c_{m 1}\right) & \left(a_{m 2}, b_{m 2}, c_{m 2}\right) & \cdots & \left(a_{m n}, b_{m n}, c_{m n}\right)
\end{array}\right]
$$

Table 2: Fuzzy numbers for approximating the linguistic variable

\begin{tabular}{|c|c|}
\hline Linguistic terms & Fuzzy Numbers \\
\hline Very low (SL) & $(0.1,0.25,0.3)$ \\
\hline Low $(\mathrm{LW})$ & $(0.2,0.3,0.55)$ \\
\hline Good $(\mathrm{GD})$ & $(0.3,0.45,0.6)$ \\
\hline High $(\mathrm{HH})$ & $(0.5,0.6,0.7)$ \\
\hline Excellent $(\mathrm{EX})$ & $(0.6,0.75,0.9)$ \\
\hline
\end{tabular}

Step 2: Using a weighted normalization method, normalize the fuzzy decision matrix by multiplying each element in the column in the fuzzy decision matrix by a pre-determined weight of the fracture-based criteria $\left(\widetilde{w}_{i}\right)$.

$$
\begin{aligned}
& \tilde{V}=\left[x_{i j} \mathrm{X} \widetilde{w}_{j}\right]_{m \times n .}, \\
& \text { for } i=1, \ldots, n \text { and } \mathrm{j}=1,2, \ldots m
\end{aligned}
$$

Step 3: Determine the positive and negative ideal solution (PIS) and (NIS) respectively for the $\mathrm{FL}_{2}$ DIA model.

$$
\begin{aligned}
& A^{+}=\left\{\tilde{v}_{l}^{+}, \tilde{v}_{j}^{+}, \ldots, \tilde{v}_{m}^{+}\right\} \\
& \text {where } \tilde{v}_{j}^{+}=(1,1,1), j=1, \ldots, n \\
& A^{-}=\left\{\tilde{v}_{l}^{-}, \tilde{v}_{j}^{-}, \ldots, \tilde{v}_{m}^{-}\right\} \\
& \text {where } \tilde{v}_{j}^{+}=(0,0,0),, j=1, \ldots, n
\end{aligned}
$$

Step 4: Compute the separation measures $\left(d^{+}{ }_{i}\left(A^{+}, A_{i}\right)\right.$ and $\left(d^{-}{ }_{i}\left(A^{-}, A_{i}\right)\right.$ for each alternative from the positive ideal and negative ideal solutions using the equations below which represents the Fuzzy Normalized-Hamming distance $\mathrm{FL}_{2}$.

$$
\begin{aligned}
& d(\tilde{\tilde{A}}, \widetilde{B})_{\mathrm{FL} 2_{i+}}=\sqrt{\sum_{i=0}^{n} \frac{1}{6}\left[\left(a_{i j}-\tilde{v}_{j}^{+}\right)^{2}+4\left(b_{i j}-\tilde{v}_{j}^{+}\right)^{2}+\left(c_{i j}-\tilde{v}_{j}^{+}\right)^{2}\right]} \\
& d(\tilde{\tilde{A}}, \widetilde{B})_{\mathrm{FL} 2_{i-}}=\sqrt{\sum_{i=0}^{n} \frac{1}{6}\left[\left(a_{i j}-\tilde{v}_{j}^{-}\right)^{2}+4\left(b_{i j}-\tilde{v}_{j}^{-}\right)^{2}+\left(c_{i j}-\tilde{v}_{j}^{-}\right)^{2}\right]}
\end{aligned}
$$

Remark: At this stage, the result of the Fuzzy Normalized-Hamming distance $\left(\mathrm{FL}_{2}\right)$ is integrated with the Ideal
Alternative method (DIA) originally proposed by Tran \& Boukhatem (2008). 
Step 5: Determine the "positive ideal alternative" (PIA) where $d(\tilde{\widetilde{A}}, \widetilde{B})_{\mathrm{L} 2_{\mathrm{i}+}}$ is the minimum value and $d(\tilde{A}, \widetilde{B})_{\mathrm{L} 2_{\tilde{i}-}}$ the maximum. The PIA is given as; (Tran \& Boukhatem 2008).

$$
\mathrm{PIA}=\min d(\tilde{\tilde{A}}, \tilde{B})_{\mathrm{L} 2_{\mathrm{i}_{+}}}, \max d(\tilde{\tilde{A}}, \tilde{B})_{\mathrm{L} 2_{\tilde{i}_{-}}}(7)
$$

Step 6: Using the PIA values in Step 5, determine the distance of an alternatives

$$
\begin{aligned}
& P I A_{D_{i}}= \\
& \sqrt{\left[\left(d(\tilde{A}, \tilde{B})_{\mathrm{L} 2_{i+}}-\min d(\tilde{A}, \tilde{B})_{\mathrm{L} 2_{i+}}\right)^{2}+\left(d(\tilde{A}, \tilde{B})_{\mathrm{L} 2_{i_{-}}}-\max d(\tilde{A}, \tilde{B})_{\mathrm{L} 2_{i_{-}}}\right)^{2}\right]}
\end{aligned}
$$

Step 8: Finally, the $P I A_{D_{i}}$ is ranked in the descending order

\section{Numerical application of the FL2DIA model for evaluating adhesive materials}

The objective of using FL2DIA model in this study, is to holistically evaluate the different families of adhesive materials used in joining wind turbine blades system with respects to some selected fracture mechanics-based criteria and to identify potential adhesive material for the formation of joints in commercial aircraft.

In using the implementation steps for the $\mathrm{FL}_{2}$ DIA model stated in Section 2, the different adhesive materials with respects to the fracture mechanics-based criteria are evaluated. It is important to note here that the weights for the criteria were pre- determined prior to the evaluation, the criteria were all found to be equal (i.e. equal to 1). This is due to the sensitivity of the using criteria as it relates to the different adhesive materials. In another word, no one criterion is found to be more important than the other when evaluating these adhesive materials.

The experts employed in the evaluation of the criteria and the adhesive materials in this study, were all drawn from the academia. Prior to the evaluations, they were all brief on the purpose of the study and the need to critically examine the questionnaire before answering them. The expert's ratings $\left(E_{i}\right)$ of the different adhesive materials with respect to the criteria are presented in Table 3 and 4 , were the information consists of linguistic variables, and the converted fuzzy numbers which represent the comprehensive decision matrix of the $\mathrm{FL}_{2}$ DIA model. 
Table 3: Ratings of the of the Adhesive materials with respect to the criteria

\begin{tabular}{|c|c|c|c|c|c|c|c|c|c|c|c|c|}
\hline $\mathrm{C}_{\mathrm{i}}$ & $E_{1}$ & $\mathrm{E}_{2}$ & $E_{3}$ & $E_{1}$ & $\mathrm{E}_{2}$ & $\mathrm{E}_{3}$ & $\mathrm{E}_{1}$ & $\mathrm{E}_{2}$ & $\mathrm{E}_{3}$ & $\mathrm{E}_{1}$ & $\mathrm{E}_{2}$ & $E_{3}$ \\
\hline & \multicolumn{3}{|c|}{$\mathrm{C} 1$} & \multicolumn{3}{|c|}{$\mathrm{C} 2$} & \multicolumn{3}{|c|}{ C3 } & \multicolumn{3}{|c|}{$\mathrm{C} 4$} \\
\hline $\mathrm{A}_{1}$ & LW & GD & SL & $\mathrm{HH}$ & LW & $\mathrm{HH}$ & SL & $\mathrm{HH}$ & GD & GD & LW & SL \\
\hline $\mathrm{A}_{2}$ & $\mathrm{HH}$ & $\mathrm{HH}$ & SL & EX & GD & EX & LW & EX & $\mathrm{HH}$ & SL & GD & LW \\
\hline $\mathrm{A}_{3}$ & EX & EX & LW & SL & $\mathrm{HH}$ & $\mathrm{HH}$ & GD & $\mathrm{HH}$ & EX & LW & $\mathrm{HH}$ & GD \\
\hline $\mathrm{A}_{4}$ & $\mathrm{HH}$ & $\mathrm{HH}$ & GD & LW & GD & GD & LW & LW & $\mathrm{SL}$ & GD & LW & SL \\
\hline $\mathrm{A}_{5}$ & $\mathrm{HH}$ & GD & LW & GD & $\mathrm{HH}$ & GD & $\mathrm{HH}$ & GD & LW & LW & GD & LW \\
\hline $\mathrm{A}_{6}$ & $\mathrm{SL}$ & GD & $\mathrm{HH}$ & $\mathrm{H}$ & EX & $\mathrm{HH}$ & EX & LW & $\mathrm{SL}$ & GD & $\mathrm{HH}$ & GD \\
\hline $\mathrm{A}_{7}$ & LW & $\mathrm{HH}$ & $\mathrm{SL}$ & EX & $\mathrm{HH}$ & $\mathrm{HH}$ & LW & GD & LW & $\mathrm{HH}$ & GD & $\mathrm{HH}$ \\
\hline $\mathrm{A}_{8}$ & $\mathrm{HH}$ & EX & LW & $\mathrm{SL}$ & EX & EX & GD & $\mathrm{HH}$ & GD & GD & $\mathrm{HH}$ & LW \\
\hline $\mathrm{A}_{9}$ & SL & $\mathrm{HH}$ & $\mathrm{HH}$ & $\mathrm{SL}$ & $\mathrm{HH}$ & $\mathrm{HH}$ & $\mathrm{SL}$ & GD & SL & GD & $\mathrm{SL}$ & GD \\
\hline $\mathrm{A}_{10}$ & LW & $\mathrm{SL}$ & EX & LW & EX & EX & LW & LW & LW & $\mathrm{HH}$ & LW & $\mathrm{HH}$ \\
\hline $\mathrm{A}_{11}$ & GD & LW & $\mathrm{HH}$ & SL & $\mathrm{HH}$ & $\mathrm{HH}$ & GD & GD & GD & EX & GD & $\mathrm{HH}$ \\
\hline $\mathrm{A}_{12}$ & SL & $\mathrm{HH}$ & GD & $\mathrm{HH}$ & $\mathrm{HH}$ & GD & $\mathrm{SL}$ & $\mathrm{HH}$ & $\mathrm{HH}$ & LW & EX & GD \\
\hline $\mathrm{A}_{13}$ & LW & SL & EX & $\mathrm{SL}$ & SL & SL & $\mathrm{SL}$ & SL & $\mathrm{HH}$ & GD & $\mathrm{HH}$ & $\mathrm{HH}$ \\
\hline $\mathrm{A}_{14}$ & $\mathrm{HH}$ & LW & $\mathrm{HH}$ & GD & $\mathrm{LW}$ & GD & GD & LW & $\mathrm{HH}$ & LW & EX & GD \\
\hline
\end{tabular}

Table 4: Decision matrix for the $\mathrm{FL}_{2}$ DIA method

\begin{tabular}{|l|c|c|c|c|}
\hline & $\mathrm{C} 1$ & $\mathrm{C} 2$ & $\mathrm{C} 3$ & $\mathrm{C} 4$ \\
\hline $\mathrm{A}_{1}$ & $(0.20,0.33,0.48)$ & $(0.40,0.50,0.65)$ & $(0.30,0.43,0.53)$ & $(0.20,0.33,0.48)$ \\
\hline $\mathrm{A}_{2}$ & $(0.37,0.48,0.57)$ & $(0.47,0.65,0.80)$ & $(0.43,0.55,0.72)$ & $(0.20,0.33,0.48)$ \\
\hline $\mathrm{A}_{3}$ & $(0.47,0.60,0.78)$ & $(0.37,0.48,0.57)$ & $(0.47,0.60,0.73)$ & $(0.33,0.45,0.62)$ \\
\hline $\mathrm{A}_{4}$ & $(0.43,0.55,0.67)$ & $(0.27,0.40,0.58)$ & $(0.17,0.28,0.47)$ & $(0.20,0.33,0.48)$ \\
\hline $\mathrm{A}_{5}$ & $(0.33,0.45,0.62)$ & $(0.37,0.50,0.63)$ & $(0.33,0.45,0.62)$ & $(0.23,0.35,0.57)$ \\
\hline $\mathrm{A}_{6}$ & $(0.30,0.43,0.53)$ & $(0.53,0.65,0.77)$ & $(0.30,0.43,0.58)$ & $(0.37,0.50,0.63)$ \\
\hline $\mathrm{A}_{7}$ & $(0.27,0.38,0.52)$ & $(0.53,0.65,0.77)$ & $(0.23,0.35,0.57)$ & $(0.43,0.55,0.67)$ \\
\hline $\mathrm{A}_{8}$ & $(0.43,0.55,0.72)$ & $(0.43,0.58,0.70)$ & $(0.37,0.50,0.63)$ & $(0.33,0.45,0.62)$ \\
\hline $\mathrm{A}_{9}$ & $(0.37,0.48,0.57)$ & $(0.37,0.48,0.57)$ & $(0.17,0.32,0.40)$ & $(0.23,0.38,0.50)$ \\
\hline $\mathrm{A}_{10}$ & $(0.30,0.43,0.58)$ & $(0.47,0.60,0.78)$ & $(0.20,0.30,0.55)$ & $(0.40,0.50,0.65)$ \\
\hline $\mathrm{A}_{11}$ & $(0.33,0.45,0.62)$ & $(0.37,0.48,0.57)$ & $(0.30,0.45,0.60)$ & $(0.47,0.60,0.73)$ \\
\hline $\mathrm{A}_{12}$ & $(0.30,0.43,0.53)$ & $(0.43,0.55,0.67)$ & $(0.37,0.48,0.57)$ & $(0.37,0.50,0.68)$ \\
\hline $\mathrm{A}_{13}$ & $(0.30,0.43,0.58)$ & $(0.10,0.25,0.30)$ & $(0.23,0.37,0.43)$ & $(0.43,0.55,0.67)$ \\
\hline $\mathrm{A}_{14}$ & $(0.40,0.50,0.65)$ & $(0.27,0.40,0.58)$ & $(0.33,0.45,0.62)$ & $(0.37,0.50,0.68)$ \\
\hline
\end{tabular}


In Step 3-8 of the $\mathrm{FL}_{2}$ DIA model algorithm, the decision matrix presented in Table 4 is normalized to form the weighted normalized decision matrix. Thereafter, the Fuzzy Normalized-Hamming distance $\left(\mathrm{FL}_{2}\right)$ to the positive and negative alternatives is computed. From the Fuzzy NormalizedHamming distance the PIA is determine and finally, the PIA result is ranked in the descending order as shown in Table 5.

Table 5: The FL ${ }_{2}$ DIA result

\begin{tabular}{|l|c|c|c|c|c|}
\hline & $d(\tilde{\tilde{A}}, \widetilde{B})_{\mathrm{L} 2_{i+}}$ & $d(\tilde{A}, \widetilde{B})_{L 2_{i-}}$ & $P I A_{D_{i}}$ & Ranking \\
\hline $\mathrm{A}_{1}$ & 1.218 & 0.827 & 0.376 & 12 \\
\hline $\mathrm{A}_{2}$ & 1.032 & 1.045 & 0.093 & 3 \\
\hline $\mathrm{A}_{3}$ & 0.951 & 1.092 & 0.000 & 1 \\
\hline $\mathrm{A}_{4}$ & 1.234 & 0.833 & 0.384 & 13 \\
\hline $\mathrm{A}_{5}$ & 1.126 & 0.914 & 0.249 & 10 \\
\hline $\mathrm{A}_{6}$ & 1.023 & 1.031 & 0.094 & 4 \\
\hline $\mathrm{A}_{7}$ & 1.063 & 1.016 & 0.135 & 7 \\
\hline $\mathrm{A}_{8}$ & 0.972 & 1.062 & 0.036 & 2 \\
\hline $\mathrm{A}_{9}$ & 1.198 & 0.841 & 0.351 & 11 \\
\hline $\mathrm{A}_{10}$ & 1.097 & 0.976 & 0.186 & 9 \\
\hline $\mathrm{A}_{11}$ & 1.026 & 1.012 & 0.110 & 5 \\
\hline $\mathrm{A}_{12}$ & 1.034 & 0.995 & 0.127 & 6 \\
\hline $\mathrm{A}_{13}$ & 1.243 & 0.831 & 0.391 & 14 \\
\hline $\mathrm{A}_{14}$ & 1.075 & 0.960 & 0.180 & 8 \\
\hline
\end{tabular}

From Table 5, it is not hard to see that the adhesive material with the highest potential to be used for joining the wind turbine blade with respect to the fracture mechanics-based criteria is the Acrylic adhesive material which is represented with the code $A_{3}$. The study can conclude therefore that, the procedure described for the evaluation of the adhesive material has led to the selection of the best structural adhesive for bonding the
FRP wind turbine blade. This has also confirmed in the following literatures (Arenas et al., 2012; Briggs \& Jialanella, 2010) where Acrylic adhesive material is confirmed as one of the strongest adhesives for bonding metal, glass and plastic. It requires a minimum surface preparation before its applications in joints and has been found to be one of the excellent temperature resistance adhesive materials. Hence, it is 
identified as a potential adhesive material for the formation of joints in a commercial aircraft with respect to some the selected fracture mechanics-based criteria. The study has revealed the suitability of using the proposed method for ranking alternatives in the presents of conflicting criteria.
Finally, to prove the rationality and feasibility of the $\mathrm{FL}_{2}$ DIA method, the result presented in Table 5 is compared with similar existing method (traditional fuzzy TOPSIS model) under the same condition. The comparison result which focuses on the ranking of the adhesive material shows total agreement with the proposed method. The result is shown in Table 6 .

Table 6: Comparison results for the $\mathrm{FL}_{2} \mathrm{DIA}$ and fuzzy TOPSIS

\begin{tabular}{|c|c|c|c|c|}
\hline Alternatives & $P I A_{D_{i}}$ & Ranking & $\mathrm{CC}_{\mathrm{i}}$ & Ranking \\
\hline $\mathrm{A}_{1}$ & 0.376 & 12 & 0.404 & 12 \\
\hline $\mathrm{A}_{2}$ & 0.093 & 3 & 0.503 & 3 \\
\hline $\mathrm{A}_{3}$ & 0.000 & 1 & 0.534 & 1 \\
\hline $\mathrm{A}_{4}$ & 0.384 & 13 & 0.403 & 13 \\
\hline $\mathrm{A}_{5}$ & 0.249 & 10 & 0.448 & 10 \\
\hline $\mathrm{A}_{6}$ & 0.094 & 4 & 0.502 & 4 \\
\hline $\mathrm{A}_{7}$ & 0.135 & 7 & 0.489 & 7 \\
\hline $\mathrm{A}_{8}$ & 0.036 & 2 & 0.522 & 2 \\
\hline $\mathrm{A}_{9}$ & 0.351 & 11 & 0.413 & 11 \\
\hline $\mathrm{A}_{10}$ & 0.186 & 9 & 0.471 & 9 \\
\hline $\mathrm{A}_{11}$ & 0.110 & 5 & 0.496 & 5 \\
\hline $\mathrm{A}_{12}$ & 0.127 & 6 & 0.490 & 6 \\
\hline $\mathrm{A}_{13}$ & 0.391 & 14 & 0.401 & 14 \\
\hline $\mathrm{A}_{14}$ & 0.180 & 8 & 0.472 & 8 \\
\hline
\end{tabular}




\section{Conclusion}

In this paper, a new method which is based on the integration of a Fuzzy NormalizedHamming distance and Ideal Alternative (FL $\mathrm{F}_{2}$ DIA) method is proposed for the holistic evaluation of the different families of adhesive materials used in the formation of joints in mechanical systems including wind turbine blades. The adhesive materials which are evaluated with respect to the fracture mechanics-based criteria (fracture toughness $C_{1}$, crack-resistance $C_{2}$, yield strength $\mathrm{C}_{3}$, and fatigue threshold $\mathrm{C}_{4}$ ) used expert-based opinion to select the best alternative.

From the result which shows that Acrylic adhesive material $\left(\mathrm{A}_{3}\right)$ has the highest potential to be used for joining the wind turbine blade based on the fracture mechanics-based criteria. We can conclude that the procedure described for the evaluation of the adhesive material has led to the selection of the best structural adhesive to bond the FRP wind turbine blade. Also, it has revealed the suitability, rationality, and feasibility of using the proposed method for ranking the different adhesives materials. Furthermore, the results have been compared with a similar existing model -traditional fuzzy TOPSIS model- under the same condition. The comparison result which focuses on the ranking of the adhesive material shows total agreement. In future research, a method for the calculation of the criteria weights will be integrated into the method; this is to account for criteria that may have different sensitivity.

\section{References}

Aikhuele, D. O., \& Turan, F. B. M. (2017).
An Integrated Fuzzy Dephi and IntervalValued Intuitionistic Fuzzy M-Topsis Model for Design Concept Selection. Pakistan Journal of Statistics and Operation Research, (2), 425-438.

Aikhuele, D. O., \& Turan, F. M. (2016). An Interval Fuzzy-Valued M-TOPSIS Model for Design Concept Selection. In The National Conference for Postgraduate Research 2016, Universiti Malaysia Pahang (pp. 374-384).

Arenas, J. M., Alia, C., Blaya, F., \& Sanz, A. (2012). Multi-criteria selection of structural adhesives to bond ABS parts obtained by rapid prototyping. International Journal of Adhesion and Adhesives, 33, 6774.

Briggs, P. C., \& Jialanella, G. L. (2010). Advances in acrylic structural adhesives. In P. 1 (Ed.), Advances in structural adhesive bonding. Elsevier, (pp. 132-150).

Campilho, R., Banea, M., Pinto, A., da Silva, L., \& de Jesus, A. (2011). Strength prediction of single-and double-lap joints by standard and extended finite element modelling. International Journal of Adhesion and Adhesives. 31(5), 363-372.

Halliwell, S. (2012). Repair of fibre reinforced polymer (FRP) structures. National Composites Network, 1, 1-33.

Hollaway, L. C. (2011). Key issues in the use of fibre reinforced polymer (FRP) composites in the rehabilitation and retrofitting of concrete structures. Service Life Estimation and Extension of Civil Engineering Structures, 8.

Kelly, G. (2004). Joining of Carbon Fibre Reinforced Plastics for Automotive 
Applications. Department of Aeronautical and Vehicle Engineering Royal Institute of Technology SE-100 44 Stockholm, Sweden (pp. 1-36)

Khani, M. S. (2015). Connections in structural FRP. Master of Science Thesis, Chalmers University of Technology, Göteborg, Sweden, (pp. 1-85).

Kroll, L., Mueller, S., Mauermann, R., Gruetzner, R., Technology, F., Structures, L., \& Gmbh, E. (2011). Strength of SelfPiercing Riveted Joints for Cfrp / Aluminium Sheets. 18 Th International Conference on Composite Materials, 1(1), $1-6$.

Lahby, M., Cherkaoui, L., \& Adib, A. (2012). New Multi Access Selection Method Using Differentiated Weight of Access Interface. Applied Mathematical Sciences, 6(55), 237-242.

LeBacq C, Brechet Y, Shercliff HR, Jeggy T, S. (2002). Selection of joining methods in mechanical design. Materials \& Design, 23(4), 405-416.

Milberg, E. (2015). Boeing Completes Detailed Design for 787-10 Dreamliner. Composites Manufacturing Magazine, (pp. $1-2$.

Mishnaevsky, L., Branner, K., Petersen, H. N., Beauson, J., McGugan, M., \& Sørensen, B. F. (2017). Materials for wind turbine blades: An overview. Materials, 10(11), 124.

Mohammed, L., Ansari, M. N. M., Pua, G., Jawaid, M., \& Islam, M. S. (2015). A Review on Natural Fiber Reinforced Polymer Composite and Its Applications. International Journal of Polymer Science,
2015, 1-15.

Nicolais, L., Meo, M., \& Milella, E. (2011). Composite materials: a vision for the future.

Oltean, R., Cozmanciuc, C., \& Munteanu, V. (2009). Adhesive bonding techniques in hybrid structures made from fibre reinforced polymeric composites and concrete. Buletinul Institutului Politehnic Din Ia ŞI, (Lix), (pp. 1-7).

Papini, M., Fernlund, G., \& J.K., S. (1994). The effect of geometry on the fracture of adhesive joints. International Journal of Adhesion and Adhesives, 14(1), 5-13.

Ren, L., Zhang, Y., Wang, Y., \& Sun, Z. (2007). Comparative analysis of a novel MTOPSIS method and topsis. Applied Mathematics Research Express, (pp. 1-10).

Samborsky, D. D., Sears, A. T., Mandell, J. F., \& Kils, O. (2009). Static and Fatigue Testing of Thick Adhesive Joints for Wind Turbine Blades. In ASME Wind Energy Symposium (p. 21).

Schubel, P. J., \& Crossley, R. J. (2012). Wind turbine blade design. Energies, 5(9), 3425-3449.

Suárez, J.C., Diez de Ulzúrrun, I., Biezma, M.V., Ruiz Román, J.M., Martnez, M.A., Del Real, J.C., López, F. (2003). Case studies in adhesives selection. Journal of Materials Processing Technology, 143144, 219-224.

Tan, K., \& Saha, M. (2007). Glass FRP bonded RC beams under cyclic loading. International Journal of Concrete Structures and Materials, 1(1), 45-55. Retrieved from http://www.concrete.org/Publications/Get Article.aspx $? \mathrm{~m}=\mathrm{icap} \&$ pubID $=56235$ 
Tran, P. N., \& Boukhatem, N. (2008).

Comparison of MADM decision algorithms for interface selection in heterogeneous wireless networks. SoftCom 2008: 16th International Conference on Software, Telecommuncations and Computer Networks, (January), 119-124.

Van Straalen III, Wardenier J, Vogelesang LB, S. F. (1998). Structural adhesive joints in engineering-drafting design rules. International Journal of Adhesion and Adhesives, 18, 41-49. 